\title{
Indigenous Approaches to Housing-Induced Domestic Conflict Management in Ondo City, Nigeria
}

\author{
Bolanle Wahab ${ }^{1}$ \& Obafemi Odetokun ${ }^{2}$ \\ ${ }^{1}$ University of Ibadan, Ibadan, Nigeria \\ ${ }^{2}$ Ministry of Housing and Urban Development, Akure, Nigeria \\ Correspondence: Bolanle Wahab, University of Ibadan, Ibadan, Nigeria. E-mail: bolanle_wahab@yahoo.com
}

Received: November 4, 2013 Accepted: May 16, 2014 Online Published: June 10, 2014

doi: $10.5539 /$ jsd.v7n4p28

URL: http://dx.doi.org/10.5539/jsd.v7n4p28

\begin{abstract}
This paper presents the results of a questionnaire survey of households and housing facilities carried out in 2007 in six wards of Ondo city in Ondo State of Nigeria. A total of 421 (2.39\%) residential buildings were sampled. The study revealed that domestic conflict occurs most in tenement buildings where residents have to share facilities and amenities. This paper examines the nature, causes, and consequences of domestic conflict among residents and the methods of resolving such conflicts. It argues that indigenous strategies of conflict management work best in traditional societies and advocates their application in settlements with similar indigenous culture.
\end{abstract}

Keywords: indigenous knowledge systems, domestic conflict, conflict management, housing facilities

\section{Introduction}

Indigenous knowledge (IK) has been overhauled in all its ramifications, particularly in areas of agriculture (Radcliff et al., 1995; Richards, 1989; Warren, 1996; Warren \& Rajasekaran, 1993; Wahab, 1996) and health (WHO, 1976; Egunjobi \& Osunwole, 1996). However, there has been little research published to date regarding how IK can help to solve domestic conflict once they arise. Yet, IK is employed to resolve the majority of domestic conflict challenges in Africa. According to Richards (1992), cited in Warren et al. (1995: 476), "indigenous knowledge is now celebrated by many of its advocates as the single largest knowledge resource not yet mobilized in the development enterprise”. Peace is an unambiguous prerequisite to socio-economic, political, and environmental development of any nation. The hinderance to peace is manifested when societal unrests ensue at communal or national level, but the unseen forces behind the societal discontents are the aggregate of domestic dissatisfaction which, in turn, engenders conflict of all descriptions. Domestic discontents arise from vagaries of inadequacies plaguing the housing sector all over the world over. Substandard and insufficient domestic facilities, such as water, toilet, bathroom, kitchen, drainage, and electricity within dwelling units, often lead to domestic conflict among residents. This can make the environment look rather chaotic and sometimes with uneasy calm.

While there is a rapidly growing body of literature on types and nature of conflict and conflict management and resolution (Albert et al., 1995, Best, 2006; Dzurgba, 2010; Faleti, 2006; Otite \& Albert, 1999; Albert, 2001, 2003) particularly with respect to consensus-building methods such as negotiation and mediation, Castro and Ettenger (1996) observe that there is little on the role of local or "indigenous" mechanisms for solving disputes. Also, while there is literature on community, ethnic, political, religious, and environmental conflicts (Albert, 2001; Otite \& Albert, 1999), there is hardly any documentation of domestic conflict arising from competing for inadequate domestic necessities. Dzurgba (2010), in addressing domestic conflict, focused on marital or marriage conflict, while Kehinde (2010) only examined the management of conflicts between landlords and tenants in Lagos State of Nigeria. Domestic conflict resulting from struggle among occupants of a given house for basic housing facilities is not gender bound; it could be women versus women, men versus men, men versus women, boys versus boys, girls versus girls, boys versus girls, elderly versus elderly, young ones versus young ones, or elderly versus young ones.

In what appear as a routine, on many occasions, occupants of rooming housing, tenement buildings and apartments in big towns and cities in Nigeria queue to draw water from wells, use kitchens, toilets, bathrooms, or air-space to dry clothes in turns. Domestic conflicts of all descriptions usually ensue when any of the occupants 
intentionally breaks the line in a bid to save time or undermine others. Lack of or insufficient kitchen facilities force many occupants of tenement houses to prepare their food in the passage-way and staircase landing. As a result, any occupant passing by may inadvertently boots the pot placed on the stove, and eventually ignites quarrels. There are reported cases where payments of electricity bills led to domestic conflict because of shared meter. Conflict often breaks out too when any occupant is perceived to have failed to fulfill his/her environmental cleaning obligation.

In Nigeria, there is gross under-reporting and non-documentation of domestic conflict and violence because of cultural factors (Afrol News, 2007; Oyediran \& Isiugo-Abanihe, 2005; Aihie, 2009), yet, they are daily occurrences globally. Many of these incidents are not reported officially owing to the belief that the police and the judicial system cannot help. In spite of that, domestic conflicts are resolved locally through indigenous mechanisms at either the home or community level by a third party who is completely neutral or presumed to be.

The aim of this paper is to examine the interface between indigenous knowledge and conflict management, particularly the relevance of local dispute-resolution mechanisms for housing-induced domestic violence in Ondo City, Ondo State Nigeria. It proffers suggestions for possible adoption of traditional methods to address domestic conflict in housing areas in urbanized communities. The methodology adopted in this paper is to first examine the conceptual meanings of the terms conflict, housing, and indigenous knowledge systems. This is followed by a brief explanation of the causes, effects, and methods of conflict resolution. The third section of the paper highlights the methodology, while the fourth section presents the findings of the research. The fifth section discusses the value and potency of indigenous participatory approach to domestic conflict management in urban and rural settlements in Nigeria. The last section presents recommendations that could promote and advance the utilization of local mediation in settling disputes in housing areas.

\section{Theoretical and Conceptual Clarifications}

\subsection{Theory of Conflict}

Conflict means to clash, or engage in a fight or simply a confrontation between individuals or groups (Albert, 2003). Conflict can be explained from the point of view of antagonistic interest and incompatible goals and it "encompasses a broad spectrum of empirical phenomena ranging from disputes between individuals to wars between states" (Libiszewski, 1991:7). Conflict is the construction of a special type of reality and may be viewed as occurring along cognitive (perception), emotional (feeling), and behavioural (action) dimensions. Faleti (2006) describes conflict as a fluid and infinitely elastic concept which connotes disagreement, dispute or controversy in ideas or viewpoints held by two or more individuals/groups. Chaplin (1979), cited in Oyesola (2005), describes conflict as a simultaneous occurrence of two or more mutually antagonistic impulses or motives; while Wilson and Hanna (1990), cited in Oyesola (2005), describe conflict as a struggle involving ideas, values, and/or limited resources. Agbola and Kassim (2007) observe that the main conflict perspectives often read in the literature are Marxism, named after Karl Marx (1818-1883), and the conflict structuralism (the Weberian sociology) named after Max Weber (1864-1920). Karl Marx is credited with the development of the Conflict Theory. The basic insight of the theory is that human beings are sociable but conflict-prone-animals. The radical structural theory of conflict, represented by the Marxist dialectical school, sees incompatible interests based on competition for resources which, in most cases, are assumed to be scarce, as being responsible for social conflict (Collier, 2000, cited in Faleti, 2006). The theory looks at social problems like economic exclusion, injustice, poverty, disease, exploitation, and inequality as sources of conflict.

From conflict perspectives, when a society is characterized by inequality, some people will have more than their fair share from the society's economic resources, while others will have less. This also finds expression in the housing situation in Nigeria either in the fact that a few individuals have several housing units, while millions do not have a room of their own, or the situation whereby a few houses have adequate facilities (in terms of number and quality) for the use of residents, while tens of units in the same ward/community have neither kitchen nor bathroom nor toilet. This constitutes a strong basis for the housing-induced domestic conflict in Nigerian urban centres.

In sociology, conflict theorists assert that a society or an organization functions to enable individuals and groups strive to "maximize their benefits, which inevitably contributes to social change, such as political changes and revolutions" (Öztürk, 2004:92; Obaro, 2013:395). Conflict theory offers a useful lens with which to analyze society, especially to explain the kind of relationship and hostility between the haves and have-nots in any society, and people living in the same or different areas of a city. Conflict theory can be applied to property, in this case, housing. Karl Marx, cited in Boswell \& Dixon (1993), argues that property is held by the state thereby making property rights and ownership an issue of conflict between property owners and renters, capitalists or 
employers and their workers. The constant struggles for the use of limited and, in some cases, poor quality housing facilities, especially bathroom, toilets, kitchen, corridors/verandas, and water, among tenants and between house owners and tenants in many towns and cities in Nigeria breed routine conflicts between and among residents. This is where the conflict theory becomes relevant to the theme of this paper.

The word domestic is described as relating to or used in the home or everyday life within a household. It also relates to or involves a family or the people living together within a household (Poelmans, 2010). Dzurgba (2010) views domestic conflict as a conflict that has to do with families and homes. Domestic conflict can, therefore, be described as a disagreement or clash between members of a household or occupants/residents of a house over the use of common facilities within (water, electricity, kitchen, bathroom, toilets, stairs, laundry etc.) and around the house (drains) (Ellingsen, 2000). It is a clash of interest, ideas and principles among people co-habiting together. It also reflects the difference in the mindset, temperament, disposition and interest of people (house owners, tenants, visitors) living in a house in the use or handling, management and repair or maintenance of facilities within the house (reference). Under domestic conflict, individual residents in a house routinely struggle to maximize their own benefits in form of unlimited use of shared facilities. Domestic conflict is an incident of the home that involves abuse, scolding, yelling, booing, and sometimes physical assault (Oyediran \& Isiugo-Abanihe, 2005; Odetokun, 2007; Aihie, 2009) between a house-owner and household member(s) or among household members (female and male children), between a house-owner and tenants, or among tenants.

\subsection{The Concept of Housing and Its Relationship with Conflict Theory}

Egunjobi (1998) describes the house as a shelter that keeps one out of extreme weather conditions, such as too hot or too cold temperatures. A house, according to Wahab (2007), is any type of physical structure or a special compartmentalized enclosure (temporary or permanent) which offers shelter, protection, and identity to humans (excluding ancillary services and environmental or community facilities). A house is a part of housing and the house becomes housing when we have it in multiple of houses/units provided with basic facilities and services for the physical, mental, social, economic, health, cultural, and material well-being of individuals and families (Wiltgen \& Wahab, 1997). The services, as listed by Olatubara (2007), include potable water supply, electricity, heating, ventilation, air conditional system and so on, while the facilities include access road, drainage, sewage, and refuse disposal system, among others.

There is a very strong relationship between housing and conflict. "Conflicts arise from interpersonal relationships between tenants in the housing sector" (Agbola \& Kassim, 2007:40). Each stage of the housing development process, from site clearing to foundation laying, wall construction, roofing, utility installation and finishing generate conflict between the craftsmen/artisans and the developer or house owner. It is noted from personal observations and interactions with neighbours and professional colleagues, the conflict is not only in the management of construction materials, but also in the use of the right quality and quantity of such materials as sand, gravel and cement, theft of materials (especially the movable ones like cement, nails, electrical and plumbing materials), time of completion, which is unduly extended by the artisans to realize additional wages, deployment of personnel, and non-compliance with approved architectural design among others (reference). Housing plays major roles in day-to-day inter-relationships between and among its occupiers. It commonly provides shelter, safety, health, and psychological fulfilment (Egunjobi, 1998) and also facilitates unity and brotherhood. Yet, it provides avenue for breeding social friction between families when housing facilities increasingly become inadequate either in quality or in quantity. Frictions which lead to strained relationships characterize the interactions between landlords and tenants "due to non-prompt payment of house rent by tenants, frequent rent increment, and lack of maintenance of buildings by both the landlord and/or tenants" As Olutayo (2007:160), notes, discontent among family members or residents/tenants may arise from the failure of a member to carry out his/her domestic duty, which is usually assigned in rotation (reference). Less domestic friction is likely to be recorded between and among families or residents when a house is provided with adequate basic facilities. When people are adequately housed, they are protected from conflict (Agbola \& Kassim, 2007).

\subsection{Concept of Indigenous Knowledge System}

Indigenous knowledge system (IKS) is referred to in different terms, such as: "Indigenous Local Knowledge" (ILK) (Atteh, 1992); "Indigenous Technical Knowledge" (ITK) (Howes and Chambers, 1979; and "Community Environmental Knowledge" (CEK) (Richards, 1989). This knowledge system has also been variously defined (Warren, 1996). Warren and Rajasekaran (1993:8) define it as "the systematic body of knowledge acquired by local people through the accumulation of experiences, informal experiments, and intimate understanding of the environment in a given culture". IK is a knowledge which was evolved, institutionalized, and perfected by the people and passed on to succeeding generations through inheritance from their ancestors (Wahab, 1996). It is a 
broad-range of specialized knowledge which a community acquires, shares, and applies over generations in order to live meaningfully in a given environment (Wahab, 2010). IKS rests on a validated assumption that a community is guided by those principles and practices which they have developed over many years of experience and have transmitted from generation to generation through oral tradition (Titilola et al., 1994). It generally refers to how members of a community perceive and understand their environment and resources, particularly the way they resolve misunderstandings arising from day-to-day interactions with one another. Theoretically, since every population is unique in terms of its environment, its resources, cosmovision, and its tools (both physical and conceptual), the indigenous knowledge that a group possesses will also be unique (Castro \&Ettenger, 1996). As noted by Chimaraoke (2002:62),

Through discussions with the communities, we learnt about the use of the kolanut (Cola accuminata) and the fresh palm frond (called locally omu) as key instruments of peace negotiation and conflict resolution in Igbo society. Once one community gives these to another, the receiving community is under an obligation to accept them and also to return a similar gift.

In every traditional setting, local mechanisms are employed to resolve community disputes before they escalate to large-scale conflict (Albert et al., 1995). Local mediation integrates consensus-building which is anchored to open discussions to exchange information and clarify issues (Lewins, 2001). Parties involved in any conflict are encouraged to participate actively in the dispute-resolution process which are anchored by trusted, experienced and respected community members and leaders who often include traditional authorities-elders, chiefs-women's organizations, local institutions, priests, and professional associations (Albert et al., 1995).In the conflict resolution process, the elders function as a court with broad and flexible powers to interpret evidence, pronounce and enforce judgments, and manage the process of reconciliation (Albert et al., 1995). The conflict mediator leads the discussion of the problem, while the elders or other traditional mediators use their power of judgment and position of moral pre-eminence and superiority to find an accepted solution to the conflict under deliberation (Brock-Utne, 2001). Indigenous processes are long-term interactions; mediation continues until a solution that is acceptable to all parties is found. Some peace conferences can go on for months simply because the intervening elders see their traditional objectives in conflict resolution as not that of accusations and counter-accusations, but soothing hurt feelings and reaching a compromise or conciliation that may help to improve future relationships among parties. Thus, traditional conflict resolution mechanisms can bring about long-term reconciliation Brock-Utne (2001), which is one of its significant merits.

\section{Literature Review}

Ropers (2002) assert that conflicts are a phenomenon associated with inevitable corollary of co-existence in all societies, and, to some extent, are an inevitable and indeed a necessary corollary of social change. Conflicts are an expression of tensions and incompatibilities between different and mutually independent parties with regard to their respective needs, interest, and values. A conflict is simply "a difference we don't like." (Robinson, 2009:141).

It is noteworthy that, generally, human beings may not act violently towards each other except there is a meeting point in a social interaction (Odetokun, 2007). Simmie (1980) identifies four main parameters of the forms of social interaction: total co-operation, total anomic, total alienation, and total conflict, which are all relatively undesirable forms of social interactions. Totally cooperative and integrated societies are static. Wholly anomic individuals suffer from the malady of insatiable but dissatisfied aspirations. An alienated man is an object rather than a person (Simmie, 1980). Wright's definition of conflict as "opposition among social entities directed against one another" is relevant here (Wright, 1990:19, quoted in Albert, 2001:1-2). Albert (2001) underscores "opposition" in contrast to "cooperation". This means that when people living in a housing area for example, are not cooperating, then they are simply in opposition which may take the form of hostility and later may turn either physical or psychological. When the level of opposition becomes unbearable to some residents and attracts booing, yelling, scolding and abusing, then total conflict sets in which may lead to physical assault and then violence. When residents of a house (women and girls, men and boys) do not cooperate with one another to take care of the house and its surroundings (physical environment), there exists basis of total conflict, which is housing-induced. Residents in a dwelling co-operate when they behave in a manner to satisfy their needs as well as those of the other people they co-habit or relate with.

For all these relationships to manifest, there must be a point of convergence, in this respect, a house. Decent housing (adequate shelter) is one of the basic needs of every individual, the family, and the community in general. As a prerequisite to the survival of man, it ranks second only to food. In Nigeria, statistics show that houses in urban areas are generally overcrowded and lack basic amenities. According to the National Bureau of 
Statistics (2009), cited in Amaefule (2011), in 2008, 66.3\% of Nigerian households lived in a single room, only $27.2 \%$ lived in whole buildings, $38.3 \%$ had covered pit latrines, $15.7 \%$ have uncovered pit latrines, $0.6 \%$ have Ventilated Improved Pit (VIP)toilets, while 8.8\% did not have any toilet facility. In Oyo State, 53.3\% households did have toilet facilities in 2008. Akorede (1995) found that the larger proportion of the residential houses in Ondo, in Western Nigeria, did not have the necessary basic facilities and that houses in the traditional area of the city were of low quality in terms of walls and roofs. He claims that about $74 \%$ of the sampled building had pit latrines located at the rear of the houses. Poverty is an important factor in domestic conflict; it explains why some people are confined to poor quality houses and neighbourhoods, which are characterized by inadequate or outright lack of basic facilities.

\subsection{Causes of Domestic Conflict}

Domestic conflicts may arise from housing difficulties, unsanitary residential environments or as a result of co-sharing of facilities and amenities. An unclean environment is observed to cause misunderstanding and consequently conflict among residents, especially those of rented apartments. Narrating the causes of conflict in Kenya, Amman and Duraiappah (2011) aver that deteriorating environmental and social welfare conditions have resulted in an increase in conflicts between the indigenous inhabitants of the district and the newcomers, with violent and bloody outcomes in many cases. In his study of conflicts between landlords and tenants in Lagos State, Nigeria, Kehinde (2010) notes that conflicts were caused by house renovation (16.0\%), refusal to pay for utility bill (5.3\%), intolerance (5.3\%), parking space (1.3\%), and use of generating set (1.3\%), among others.

Cleaning of the house surroundings is an activity that frequently causes serious domestic conflicts, as no tenant wishes to take up the responsibility. For example, as reported by the Sunday Tribune of $11^{\text {th }}$ March, 2007, cited in Odetokun (2007), a pregnant woman was beaten to death in Lagos by a co- tenant for reminding the tenant to clean the compound. This came as a result of the deceased's report of the occupant to the caretaker for negligence of duty in cleaning the compound. The reported occupant revolted by beating up the reporter (the deceased). The pregnant woman later died in the hospital. Other causes of domestic conflicts are poverty and unequal incomes of occupants. These generate jealousy and envy and may later lead to hatred.

\subsection{Effects of Domestic Conflict}

Conflict affects the occupants of dwellings psychologically. From personal observations, coupled with informal discussion of residents in some low-income communities in Ibadan, it is believed that conflict within the house often results in a noisy environment, which may have effects on the hearing of dwellers, cause distraction, and lead to hatred among residents. On the immediate environment, conflict usually results in unclean environment owing to the fact that nobody wishes to take up the responsibility of cleaning the surroundings. Infectious diseases could spread under such unsanitary conditions. The consequences of conflict between landlords and tenants in Lagos State, as observed by Kehinde (2010), include strained relationship, confrontation, malice, litigation, disconnection of power supply, rent increase, and quit notice. One of the inherent thrusts or consequences of conflict is that it moves people away from intimacy (Robinson, 2009).

Domestic conflict disrupts existing social and internal harmony in any given relationships (Hwang, 1998). It also leads to frustration between landlords and tenants, especially when it is time to pay house rent (Olutayo, 2007). It is believed to have contributed significantly to high-conflict divorce that impacts negatively on the actors involved, particularly the children (Johnston, 1994). Domestic conflict exposes actors to violence and encourages the use of it to settle an old score (DuRant et al. 1994). Such previous exposure includes witnessing violence on television and in movies, in the community, and in the home (Widom, 1989; Roseberg et al., 1992). It has been observed that domestic violence can provoke suicide (Websdale, 2003). The 2003 Massachusetts Domestic Violence Homicide Report notes that suicide can be attributed to domestic violence incidents (Lauby et al., 2006) which has accounted for significant death among male victims (Davis, 2010). Baker, et al. (2003) reported that a number of homelessness resulted from domestic violence. Increasing gap among ethnic nationalities has also been aggravated due to domestic violence (Ellingsen, 2000).

\subsection{Conflict Resolution Methods}

According to Oyeshola (2005), there are many ways to resolve conflicts, but conflicts can be resolved using two basic approaches, namely: peaceful negotiation or arbitration and force. Resolving conflicts by force is generally inadequate and can make the conflict protracted and difficult to manage. Most societies, therefore, prefer peaceful resolution to open combat and they all have a framework of laid-down conventions or rules by which conflicts are resolved. According to Wardak (2005), the existing body of literature confirms that the nature and causes of conflicts and the mechanisms for resolving them are deeply rooted in the culture and history of every society. Panchayat in India (Baxi \& Gallanter, 1979; Moore, 1985), Mediation Committees in China (Clark, 
1989; Liu \& Palermo, 2009), and Jirga in Afghanistan (Carter \& Connor, 1989; Rubin, 1995), that operate as informal mechanisms of conflict resolution differ from one another significantly. Jirga is a historical and traditional institution of the Pashtun of Afghanistan, where adult males gather and sit in a large circle in order to resolve tribal and national political, social, economic, cultural and religious conflicts and make collective and authoritative decisions (Rafi, 2002). The jirga includes all adult males and rules by consensus (Rubin, 1995:42). NyayaPanchayats (NPs) are India's village courts or tribunals which evolved from age-long traditional institutions that have existed in India. The NPs are decentralized, popular adjudicative body which "consist of five or more village or caste members gathered to judge disputes or determine group policy" (Baxi \& Galanter, 1979). NP's are established for groups of 7 to 10 villages each, or a total of about 15,000 people. Their membership was chosen from the leading members of a caste; they apply indigenous norms and make decisions by unanimity (Baxi \& Gallanter, 1979). "After listening to all the available information and exposing the underlying issues, the Panchayat would negotiate a solution acquiesced in by all participants" (Meschievitz \& Galanter, 1982:49). Mediation is the preferred form of conflict resolution by a traditional Chinese, as going to court is considered immoral (Liu \& Palermo, 2009:59). Mediation is organised in different forms: by a clan leader; by relatives or friends; by neighbours; by respected persons in the village; or by a respected leader of a trade. In all of these, mediation by a people's mediation committee is the most important, as it is legitimized by the government and by law (Liu and Palermo, 2009). Mediation is expected to follow any published law, policy, or rules and where there is none in respect of a matter being considered, the mediation committee will follow the "social mores and ethics" to mediate a dispute (Liu \& Palermo, 2009; State Council, 1989). As a rule, mediation is to be based on the voluntary participation of all parties in a dispute, and each party must be treated fairly and justly by the people's mediation committee.

More importantly, all these traditional forms of conflict resolution are fundamentally different from the ways conflicts are resolved in much of the Western world (Reichel, 1998). Conflict resolution in the indigenous way of the Yoruba cultural context, for example, includes cross-examination and it is the process of adducing evidence and corroborating facts of dispute which can be seen fundamentally as a legal display of wits and intelligence on the part of the legal officials (Oyeshola, 2005).

Olokesusi (1997), in his study of environmental conflicts in Nigeria's petroleum industry, observes that environmental mediation (EM) is one frequently used alternative dispute resolution (ADR) technique. He explores the applicability of public involvement (PI) and EM techniques to Nigeria's petroleum industry, as adopted in the United States (US) for conflict management during the siting of hazardous waste management facilities, such as the ECOFLO Hazardous Waste Plant in Greensboro, North Carolina. He observes that, although an impasse ensued in the city of Eau Claire case, mediation was successfully used to reach an agreement and to get a solid waste management facility sited. Mediation is an integral part of public involvement (Crowfoot \& Wondolleck, 1990) and the process of mediation in conflict management is as old as the different Nigerian traditional social organisations which have used the technique to manage many conflicts (Olokesusi, 1997).

The traditional conflict management and resolution technique utilizes community members who are versed in community-based judicial and legal decision-making apparatus to resolve conflicts in their communities (Pkalya et al., 2004). This approach facilitates dialogue and also creates a sense of unity and togetherness among the parties in conflict. Traditional mediation (TM) is effective in dealing with interpersonal and/or group conflicts as in the case of housing residents (Umbreit, 1988). The TM approach has been used at the grass-roots level to settle disputes over land, water, grazing-land rights, fishing rights, marital problems, inheritance, ownership rights, murder, bride price, cattle raiding, theft, rape, banditry, and inter-ethnic and religious conflicts (Pkalya et al., 2004).

The contemporary approaches to conflict resolution include conflict management and conflict resolution. Conflict management, as the concept implies, manages conflict rather than presenting a permanent solution to conflict, which is the goal of the second (Lefevre et al., 2002) Conflict resolution aims at helping conflicting parties to arrive at agreed compromises (Oyeshola, 2005). Conflict resolution instruments and strategies are fashioned after age-old indigenous ways of resolving misunderstandings and have been employed to resolve conflicts even in war-ravaged communities (Gang, 2011).

On the reliability and people's readiness to utilize community-based institution to resolve conflicts or disputes, a district prosecutor said:

If a case is formally filled with the government, it is very difficult to resolve it in a short time because it has to pass through all stages of the legal process. One case takes a minimum of three 
or four months, depending on how complicated it is. As I think, my idea might not be good for you or for someone else, but if disputes are resolved by community elders now that the shura is established, then it is good for everyone... (Gang, 2011:41).

This corroborates the veracity of indigenous approaches to conflict resolution. The strengths of indigenous conflict resolution strategies have been identified as against the orthodox method of conflict management. Lanek (1999), cited in Brock-Utne (2001), asserts that the Western legal approach emphasizes establishing guilt and executing retribution and punishment without reference to the victim or the wider families or future reincorporation of the offender into the community. This is in line with a Yoruba saying that: Olorun kofe iku elese bi ko se pe koro'nu p'iwada (God does not want the death of an offender but that he should turn a new leaf).

The traditional conflict resolution mechanisms among the pastoralist's communities of East Africa "aim to resolve conflicts locally, by... replacing external dispute resolution and thereby reducing reliance on external structures" (Guleid, 2007:16). Traditional mediation (TM) techniques (Shah and Shah, 1995; Humphries, 2002) help the community to enforce and sustain the result of the dispute (Guleid, 2007). The TM approach presents a least-cost and time-saving means of resolving conflicts (Toolbox, 2012).Kehinde (2010) observes that tenants in conflict with their landlords in Lagos, Nigeria considered litigation as cumbersome (10.7\%), prolongs case unnecessarily (37.3\%) and is ineffective (12\%). Under the indigenous participatory conflict resolution, native intelligence, historical evidences, reference to the ancestors of feuding parties, stories, proverbs, and other local verbal and non-verbal resources are employed by mediators using the native language.

The indigenous participatory technique has been used by Rodriguez (1998) in the resolution of conflicts in National Parks in Venezuela; Scholte et al., (1999) used it to resolve conflict situation in National Parks in Cameroon; while Chimaraoke (2002) used it to resolve a clash between two local communities (Abala \& Ntighauzor Amairi) in Abia State, Nigeria. Humphries (2002) reported how Newcastle City Council in England utilized participatory methods to facilitate stakeholder dialogue and conflict resolution to address the stress (increased noise, parked cars, and a general perception of antisocial behaviour) brought to residents by the high local levels of student occupancy.

The distinguishable features of indigenous conflict resolution mechanisms from Western methods of resolving disputes have been identified. One of the differences is the oral presentation of evidences during indigenous conflict resolution processes. The appointment of respected elders, with no formal training as mediators as against any trained mediator, is another (Chimaraoke, 2002). Western approaches require no spiritual invocation, but ritualistic (non-fetish) manipulation is an integral part of indigenous conflict resolution agenda.

\section{The Study Setting and Methodology}

The study area is Ondo city, the headquarters of Ondo West Local Government Area of Ondo State. Ondo is one of the ancient Yoruba cities with traits of indigenous artifacts in southwestern Nigeria. Ondo city lies approximately between longitude $4.2^{\circ} \mathrm{E}$ and $5.6^{\circ} \mathrm{E}$, and latitude $6.3^{\circ} \mathrm{N}$ and $8.1^{\circ} \mathrm{N}$ (see Fig. 1) and it is characterized by tropical climate. It is located in the heart of the cocoa-producing region of southwestern Nigeria. Ondo State Government (2012) puts the population of Ondo city at 283, 672, with 139, 400 males and 144, 272 females. The morphology of the city is typical of traditional Yoruba settlements, with the king's palace and market at the centre, from where streets radiate outward to other parts of the city. The central part of the city contains old and traditional buildings, while the outer part contains recent and modern buildings. 


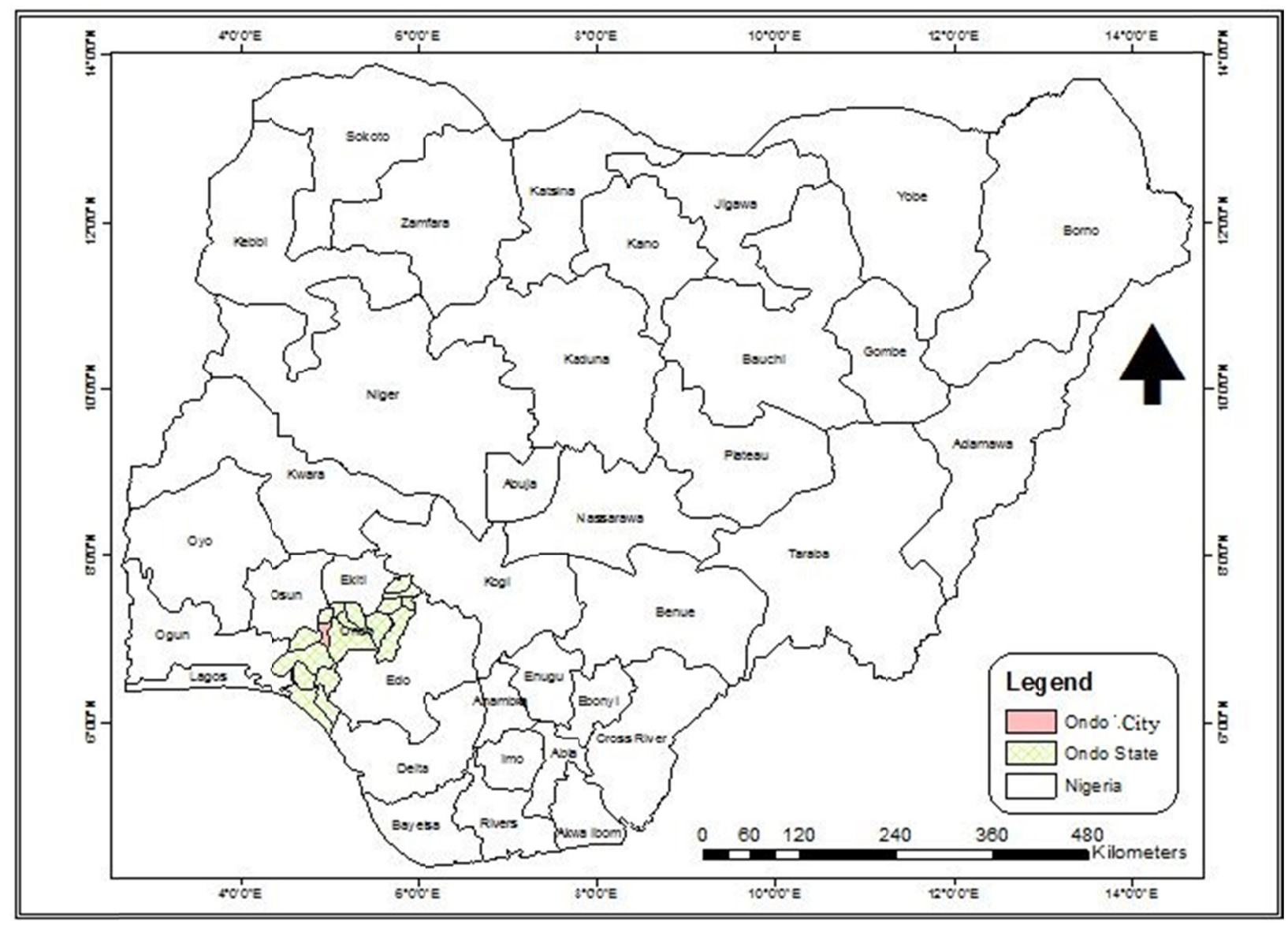

Figure 1. Ondo city within the context of Nigeria

Source: GIS Lab, Department of Geography, University of Ibadan (2012)

Primary and secondary data were used in this study. The primary information was obtained from questionnaire administration conducted in 2007. Secondary data were collected from the available literature, Ondo West Local Government provided information on housing stock, and the State Ministry of Works provided map of the city. The case study approach was adopted in this study with the scope limited to Ondo West Local Government area, which has twelve political wards. Out of the twelve wards, the six metropolitan wards - 1, 7, 8,9,10, and 11- that constitute the city were selected for primary data collection. The total number of buildings in the six wards was 16,336 as at 2004 projected to 17,601 for 2006 , using $3.8 \%$ growth rate obtained from Ondo West Local Government (OWLG) in 2007). 2.39\% (421) of the total projected buildings were sampled and this covered the four house types existing in the study area: Brazilian (face-to-face), detached self-contained, multiple flat buildings, and semi-detached self-contained (Table 1).

Table 1 presents details of house type and number sampled in each of the selected six wards, where a 60 -item questionnaire was administered. The questionnaire was divided into four sections. Section "A" covered socio-economic characteristics of the respondents (gender, age, marital status, occupation, income level and educational attainment among others). Section "B" covered housing characteristics and physical condition, including type, age, height, materials of construction of the buildings, number of rooms and occupancy ratio, condition of walls, roofs and installations, and level of maintenance among others. Section " $\mathrm{C}$ " contained questions on types and number of facilities such as water, electricity, toilet, bathroom, kitchen, drainage and solid waste disposal among others. Section " $D$ " of the questionnaire contained items specifically addressing domestic conflict in the respondents' houses: types, frequency and causes of conflict, effects and the resolution strategies adopted, 46 houses were sampled in Ward 1, 120 in Ward 7, 105 in Ward 8, 30 in ward 9, 53 in Ward 10, and 67 in Ward 11. The purposive sampling technique was used in selecting the houses and respondents. Copies of a questionnaire was administered to any adult resident (male or female) preferably the head of household or in his/her absence, an adult who had spent at least two years in the house and was willing to be interviewed. Only 
one person was interviewed per house. The data collected were analyzed using the Statistical Package for Social Sciences and the derived information was presented descriptively using frequency tables and percentages.

Table 1. Allocation of questionnaire to house types in six wards

\begin{tabular}{|c|c|c|c|}
\hline Ward & House Type & Number & No. of Questionnaire Allocated (2.39\%) \\
\hline \multirow[t]{5}{*}{1} & Brazilian (Face-to-face) & 1108 & 26 \\
\hline & Detached Self-contained & 500 & 12 \\
\hline & Multiple Flat Building & 283 & 7 \\
\hline & Semi-Detached Self-contained & 21 & 1 \\
\hline & Sub-total & 1912 & 46 \\
\hline \multirow[t]{5}{*}{7} & Brazilian (Face-to-face) & 3075 & 74 \\
\hline & Detached Self-contained & 1400 & 33 \\
\hline & Multiple Flat Building & 516 & 12 \\
\hline & Semi-Detached Self-contained & 21 & 1 \\
\hline & Sub-total & 5012 & 120 \\
\hline \multirow[t]{5}{*}{8} & Brazilian (Face-to-face) & 2945 & 70 \\
\hline & Detached Self-contained & 800 & 19 \\
\hline & Multiple Flat Building & 606 & 15 \\
\hline & Semi-Detached Self-contained & 30 & 1 \\
\hline & Sub-total & 4381 & 105 \\
\hline \multirow[t]{5}{*}{9} & Brazilian (Face-to-face) & 791 & 19 \\
\hline & Detached Self-contained & 200 & 4 \\
\hline & Multiple Flat Building & 251 & 6 \\
\hline & Semi-Detached Self-contained & 19 & 1 \\
\hline & Sub-total & 1261 & 30 \\
\hline \multirow[t]{5}{*}{10} & Brazilian (Face-to-face) & 1100 & 26 \\
\hline & Detached Self-contained & 622 & 15 \\
\hline & Multiple Flat Building & 457 & 11 \\
\hline & Semi-Detached Self-contained & 24 & 1 \\
\hline & Sub-total & 2203 & 53 \\
\hline \multirow[t]{6}{*}{11} & Brazilian (Face-to-face) & 1641 & 39 \\
\hline & Detached Self-contained & 690 & 16 \\
\hline & Multiple Flat Building & 456 & 11 \\
\hline & Semi-Detached Self-contained & 45 & 1 \\
\hline & Sub-total & 2832 & 67 \\
\hline & Grand Total & 17601 & 421 \\
\hline
\end{tabular}

Source: Field Returns (2007)

\section{Findings}

The study found that $294(69.8 \%)$ of the 421 buildings sampled were of the Brazilian type (face-to-face), followed by $71(16.9 \%)$ detached self-contained buildings, $34(8.1 \%)$ multiple flat building type, while semi-detached self-contained type had the lowest number 22 (5.2\%). The highest proportion of Brazilian type of building (the rooming house) reflects the socio-economic situation of the population with the low-income earners in the majority. The survey also revealed the situation with house occupancy with $47.0 \%$ respondents 
occupying single room, $23.0 \%$ room and parlour, $18.0 \%$ occupying single flats, and $11.2 \%$ occupying whole buildings. This is a confirmation of the national housing situation of Nigerian households reported for 2008 by the National Bureau of Statistics (2009). In Ondo, most people (70.0\%) lived in single rooms and room and parlour in crowded tenement buildings where facilities were limited, overused, and had to be shared as a matter of design. In situations like that conflicts among occupants will always be anticipated due to pressure of usage of the limited sanitation facilities.

The types of toilet facilities noticed during the field survey are presented in Table 2. Of the sampled house types, $48.5 \%$ had water closet, $46.6 \%$ pit/VIP latrine, $3.1 \%$ operated bucket system, while $1.9 \%$ defecated in the bush. A cross-tabulation analysis of available toilets by house type is contained in Table 2. Considering accessibility to the toilet facilities, $229(54.4 \%)$ of the respondents indicated that the location of the toilets was extremely inconvenient, $101(24.0 \%)$ felt that the location was fairly convenient, while $91(21.6 \%)$ indicated that it was highly convenient. Most (48.5\%) of the respondents used water-dependent toilet in an environment where water supply was grossly inadequate. Cleaning of the toilets could become a problem for lack of water to flush and the result is offensive odour and health-threatening situation. This could degenerate into conflict among residents or between landlords and tenants.

Table 2. Cross-tabulation analysis of house type and available toilet facilities

\begin{tabular}{|c|c|c|c|c|c|c|c|c|c|}
\hline \multirow[t]{3}{*}{ House Type } & \multicolumn{9}{|c|}{ Type of Toilets } \\
\hline & \multicolumn{2}{|c|}{ Water Closet } & \multicolumn{2}{|c|}{ Pit /VIP } & \multicolumn{2}{|c|}{ Bucket System } & \multicolumn{2}{|c|}{ Bush } & \multirow[b]{2}{*}{ Total } \\
\hline & No. & $\%$ & No. & $\%$ & No. & $\%$ & No. & $\%$ & \\
\hline Face-to-face & 108 & 36.7 & 165 & 56.1 & 13 & 4.4 & 8 & 2.7 & 294 \\
\hline Detached Self-contained & 61 & 85.9 & 10 & 14.1 & - & - & - & - & 71 \\
\hline Semi-Detached Self-contained & 11 & 50.0 & 11 & 50.0 & - & - & - & - & 22 \\
\hline Multiple Flats & 24 & 70.6 & 10 & 29.4 & - & - & - & - & 34 \\
\hline Total & 204 & 48.5 & 196 & 46.6 & 13 & 3.1 & 8 & 1.9 & 421 \\
\hline
\end{tabular}

Source: Field Returns (2007).

The underground water supply was the major source in the study area where the majority $-320(76.0 \%)$ of the sampled respondents sourced water from the well, 67 (15.9\%) from borehole, $22(5.2 \%)$ from the stream, insignificant $10(2.4 \%)$ were supplied through public means, while $2(0.5 \%)$ depended on rain harvesting for water use. The location of water sources was another major finding, as $151(35.9 \%)$ considered the location of their water sources inconvenient; 126 (29.9\%) indicated that the location was bad; while $95(22.6 \%)$ and 49 $(11.6 \%)$ of the respondents indicated that the location was fair and very good, respectively. The implication of this is that $69 \%$ of the sampled residents in Ondo who considered the location of water facilities very inconvenient would be defaulting in cleaning shared facilities that require the use of water, such as toilets, bathrooms, kitchens, and drainages as they would be reluctant to go to the wells, boreholes, and streams to draw water.

The investigations about the availability and location of kitchen facilities are insightful. Of the entire houses sampled only 235 (55.8\%) had indoor kitchen, 167 (39.7) had outdoor kitchen, and 19 (4.5\%) had none, in which case the residents cooked within the inner passage/corridor of their houses. Cross-tabulation analysis of the available kitchen for all the house types is contained in Table 3 . The implication of this is that $44.2 \%$ of the residents using outdoor kitchen (especially the face-to-face houses) are most likely to be cooking their meals within the inner passages and verandahs of their houses, especially on rainy days and at night. The fumes from kerosene cooking stove, and charcoal fire-points, the messy floor due to water spilling from cooking activities on the public spaces (inner passages and verandah) were a veritable source of conflict among the residents. Most $(45.5 \%)$ of the respondents indicated that the location of the kitchen was extremely inconvenient. 
Table 3. Cross-tabulation analysis of house type and location of kitchen facilities

\begin{tabular}{lllllllll}
\hline Type of Buildings & \multicolumn{3}{l}{ Location of Kitchen } \\
& \multicolumn{3}{l}{ Indoor } & \multicolumn{3}{l}{ Outdoor } & None & \\
& No. & $\%$ & No. & $\%$ & No. & $\%$ & Total \\
\hline Face-to-face & 137 & 46.6 & 141 & 48.0 & 16 & 5.4 & 294 \\
Detached Self-contained & 64 & 90.1 & 6 & 8.5 & 1 & 1.4 & 71 \\
Semi-Detached Self-contained & 6 & 27.3 & 14 & 63.6 & 2 & 9.1 & 22 \\
Multiple Flats & 28 & 82.4 & 6 & 17.6 & - & - & 34 \\
Total & $\mathbf{2 3 5}$ & $\mathbf{5 5 . 8}$ & $\mathbf{1 6 7}$ & $\mathbf{3 9 . 7}$ & $\mathbf{1 9}$ & $\mathbf{4 . 5}$ & $\mathbf{4 2 1}$ \\
\hline
\end{tabular}

Source: Field Returns (2007).

In the case of bathroom facility, the survey revealed that the majority- 214 (50.8\%)- of the houses had temporary (makeshift) bathrooms located outside the buildings, 161 (38.2\%) had bathrooms within the buildings, while 46 $(10.9 \%)$ had none and either took their bath in open spaces around the house or share neighbours' facilities. A cross-tabulation analysis of house type and bathroom facility is contained in Table 4. Occupants of buildings without bathroom facilities were fond of bathing at roofless enclosures that barely covered their nakedness. This was the cause of a verbal assault between a female resident of Akingbola community near Bodija Market, Ibadan, in 2010 when another male resident peeped through the window of his single room on the first floor of a face-to-face building to have a view of the woman who was bathing in a roofless space enclosed with used corrugated iron roofing sheets. A half $-211-(50.1 \%)$ of the sampled respondents in Ondo indicated that the location of their bathrooms was extremely inconvenient.

Table 4. Cross-tabulation analysis of house type and location of bathroom

\begin{tabular}{lllllllll}
\hline & \multicolumn{3}{l}{ Location of Bathroom } & \multicolumn{3}{l}{ None } \\
\cline { 2 - 9 } & \multicolumn{2}{l}{$\begin{array}{l}\text { Temporary } \\
\text { and Outside }\end{array}$} & \multicolumn{2}{l}{ Bathroom } & & \\
& No. & $\%$ & No. & $\%$ & No. & $\%$ & Total \\
\hline Face-to-face & 181 & 61.6 & 89 & 30.3 & 24 & 8.2 & $\mathbf{2 9 4}$ \\
Detached Self-contained & 15 & 21.1 & 41 & 57.7 & 15 & 21.1 & $\mathbf{7 1}$ \\
Semi-Detached Self-contained & 11 & 50.0 & 11 & 50.0 & - & - & $\mathbf{2 2}$ \\
Multiple Flats & 7 & 20.6 & 20 & 58.8 & 7 & 20.6 & $\mathbf{3 4}$ \\
Total & $\mathbf{2 1 4}$ & $\mathbf{5 0 . 8}$ & $\mathbf{1 6 1}$ & $\mathbf{3 8 . 2}$ & $\mathbf{4 6}$ & $\mathbf{1 0 . 9}$ & $\mathbf{4 2 1}$ \\
\hline
\end{tabular}

Source: Field Returns (2007)

On solid waste disposal in Ondo city, findings revealed that $146(34.6 \%)$ of the entire sampled residents burned their waste, $63(15.0 \%)$ buried the waste, 90 (21.4\%) dumped in streams and vacant land, while only $122(29.0 \%)$ disposed of it through municipal collection. The bulk (58.8\%) of the occupants of face-to-face houses disposed of their solid waste improperly by burning or dumping in open spaces and streams. This required carrying the waste at a distance away from the house which some residents were reluctant to do. The result is that the swept waste from individual rooms and common spaces in the house were left lying about the house by whoever it was his/her turn to do so. This is a potential cause of domestic conflict if and when complaints are made against the defaulting occupier. A cross-tabulation analysis of the house types and method of waste disposal is contained in Table 5. About 10 (45.5\%) and 17 (50.0\%) of semi-detached self-contained and multiple flats houses surveyed had their waste collected by municipal authority because such residents had the ability to pay for such services. 
Table 5. Cross-tabulation analysis of house type and methods of solid waste disposal

\begin{tabular}{|c|c|c|c|c|c|c|c|c|c|}
\hline & \multicolumn{9}{|c|}{ Method of Waste Disposal } \\
\hline & \multicolumn{2}{|c|}{$\begin{array}{l}\text { Incineration/ } \\
\text { Burning }\end{array}$} & \multicolumn{2}{|c|}{$\begin{array}{l}\text { Burying of } \\
\text { waste }\end{array}$} & \multicolumn{2}{|c|}{$\begin{array}{l}\text { Municipal } \\
\text { collection }\end{array}$} & \multicolumn{2}{|c|}{$\begin{array}{l}\text { Dumping in } \\
\text { Stream/vacant land }\end{array}$} & \multirow[t]{2}{*}{ Total } \\
\hline & No. & $\%$ & No. & $\%$ & No. & $\%$ & No. & $\%$ & \\
\hline Face-to-face & 107 & 36.4 & 49 & 16.7 & 72 & 24.5 & 66 & 22.4 & 294 \\
\hline Detached Self-contained & 25 & 35.2 & 9 & 12.7 & 23 & 32.4 & 14 & 19.7 & 71 \\
\hline Semi-Detached Self-contained & 8 & 36.4 & - & - & 10 & 45.5 & 4 & 18.2 & 22 \\
\hline Multiple Flats & 6 & 17.6 & 5 & 14.7 & 17 & 50.0 & 6 & 17.6 & 34 \\
\hline Total & 146 & 34.6 & 63 & 15.0 & 122 & 29.0 & 90 & 21.4 & 421 \\
\hline
\end{tabular}

Source: Field Returns (2007).

The findings on the types of conflicts in the sampled houses in Ondo revealed that scolding, which involved cursing, was the prevalent form of domestic conflict, as $173(41.1 \%)$ of the respondents indicated. 109 (25.9\%) respondents identified fighting as the type of domestic conflict witnessed in their houses. The remaining 139 (33.0\%) respondents indicated non-conflict relationship in their dwellings (Table 6).Table 6 reveals that the face-to-face tenement type of buildings recorded the highest cases of domestic conflicts, with $47.9 \%$ of the total sampled respondents indicating the occurrence of scolding (44.2\%) and fighting (24.5\%). Only $92(31.3 \%)$ tenement residents claimed not to experience domestic conflict in their domain. 28 (39.4\%) occupants of detached self-contained buildings claimed that domestic conflict of any kind did not occur within their abode, while $20(28.2 \%)$ of them indicated that scolding was rampant in their houses. On the overall, the larger proportion of multiple flats $14(41.2 \%)$ and detached self-contained 28 (39.4\%) were the house types with highest non-occurrence of domestic conflict (see Table 6). This is understandable since the occupants hardly shared basic housing facilities with non-household members.

Table 6. House type and occurrence of domestic conflict

\begin{tabular}{lllllllll}
\hline & \multicolumn{9}{l}{ Common Conflict } \\
\cline { 2 - 9 } Souse type & Scolding & \multicolumn{3}{l}{ Fighting } & None & \\
\hline Face-to-face & 130 & $\mathbf{4 4 . 2}$ & 72 & 24.5 & 92 & 31.3 & 294 \\
Detached Self-contained & 20 & $\mathbf{2 8 . 2}$ & 23 & 32.4 & 28 & 39.4 & 71 \\
Semi-Detached Self-contained & 10 & $\mathbf{3 6 . 4}$ & 7 & 31.8 & 5 & 22.7 & 22 \\
Multiple Flats & 13 & $\mathbf{1 7 . 6}$ & 7 & 20.6 & 14 & 41.2 & 34 \\
Total & $\mathbf{1 7 3}$ & $\mathbf{4 1 . 1}$ & $\mathbf{1 0 9}$ & $\mathbf{2 5 . 9}$ & $\mathbf{1 3 9}$ & $\mathbf{3 3 . 0}$ & $\mathbf{4 2 1}$ \\
\hline
\end{tabular}

Source: Field Returns (2007)

The causes of the observed conflicts in the sampled housing areas, as the research findings revealed, included: unhealthy condition of houses, inadequate basic facilities and amenities, and uncooperative attitude of household members. Out of the 282 respondents who confirmed that conflict took place in their houses, $160(56.7 \%)$ indicated lack of basic facilities as the major cause of domestic conflicts. Another $82(29.1 \%)$ agreed that uncooperative attitudes of some occupants usually resulted in domestic conflict. The respondents who attested to unhealthy condition of houses as the cause of domestic violence were $40(14.2 \%)$ (Table 7). Out of the 421 houses sampled, only $13.1 \%$ had their windows intact, while $11.4 \%$ had fallen-off, $35.9 \%$ partially fallen-off, and $39.7 \%$ broken. Furthermore, only $30.9 \%$ of the 421 houses had their walls structurally sound, $17.1 \%$ had visible cracks, $15.4 \%$ were structurally weak, while $36.6 \%$ had their paints peeled off. The non-replacement or repair of the windows and strengthening of walls could create a row between landlords and tenants. 
Table 7. Causes of domestic conflict within the sampled houses

\begin{tabular}{lll}
\hline Causes & Frequency & Percent \\
\hline Unhealthy Condition of Houses & 40 & 14.2 \\
Lack of Facilities & 160 & 56.7 \\
Unco-operative Attitude of House Occupants & 82 & 29.1 \\
Total & $\mathbf{2 8 2}$ & $\mathbf{1 0 0 . 0}$ \\
\hline
\end{tabular}

Source: Field Returns (2007).

The study discovered incident of domestic conflicts arising from the use of water closet and earth pit latrine. A total of $152(74.55 \%)$ respondents, out of 204 using water closet in dwellings, agreed that the use of water closet had engendered domestic conflict in the past. Also, 170 (86.7\% of 196) respondents who used earth pit latrine, $12(92.3 \%)$ and $7(87.5 \%)$ houses with bucket system of latrine and those who used the nearby bushes respectively indicated that disagreements were rampant among house occupants over the use of the facility. These findings have established the fact that domestic conflicts occur in housing areas and are fundamentally caused by inadequate number and poor condition of toilet facilities.

Kitchen facilities are another veritable cause of domestic conflict, as the survey revealed. Only $116(27.6 \%)$ of the entire sampled respondents had no disagreement over the use of kitchen, with 136 (32.4\%) having minor and $169(40.1 \%)$ major disagreements. It is surprising too that almost three quarters of the respondents in houses with built-in kitchen also experienced disagreements in the use of the facility. Conversely, less than one third $116(27.2 \%)$ of the respondents had not experienced conflict in the use of kitchen facility. For the kitchen facility located outside the house, $57(34.1 \%)$ and $52(37.1 \%)$ of the respondents agreed that there occurred minor and rampant disagreements in the use of kitchen facility, respectively (Table 8). Where cooking took place in corridors of houses, $13(68.4 \%)$ and $2(10.5 \%)$ of the residents had minor and rampant disagreements respectively among themselves, respectively. This implies that inadequate kitchen facilities and the use of available ones have high propensity of causing domestic conflicts.

The inadequacy of bathroom facilities in the sampled dwellings was another concern, as $89(41.6 \%)$ of the respondents living in dwellings where temporary bathrooms were located outside buildings agreed that there were minor disagreements in the usage of bathroom facilities. In dwellings with bathrooms and bathtubs, 63 (39.1\%) and $24(21.1 \%)$ of the respondents had experienced rampant and minor conflicts, respectively. This implies that there is positive correlation between domestic conflicts and inadequate basic facilities like bathrooms, toilets, and kitchen.

Payment of electricity bill among the occupants often led to domestic conflict because $139(33.0 \%)$ and 49 $(11.6 \%)$ of the respondents agreed that there were minor and rampant disagreements each time electricity bill was to be paid. Sharing the bill according to individual consumption usually generated arguments and resistance. Unfortunately, in Ondo city, as in most parts of Nigeria, there was no electricity meters attached to individual rooms in multi-tenanted houses to record individual electricity consumption.

Table 8. Cross-tabulation analysis of location of kitchen and disagreement in its use

\begin{tabular}{lllllllll}
\hline \multicolumn{8}{l}{ Any Major Disagreement in the use of Kitchen Facility } \\
\hline & \multicolumn{2}{l}{ No Disagreement } & \multicolumn{2}{l}{ Minor Disagreement } & Rampant & \multicolumn{2}{c}{ Total } \\
\hline Location of Kitchen & No. & $\%$ & No. & \% & No. & $\%$ & No. & $\%$ \\
Kitchen inside building & 64 & 27.2 & 66 & 28.1 & 105 & 44.7 & 235 & 100 \\
Outhouse kitchen & 48 & 28.7 & 57 & 34.1 & 52 & 37.1 & 167 & 100 \\
Corridor & 4 & 21.1 & 13 & 68.4 & 2 & 10.5 & 19 & 100 \\
Total & 116 & 27.6 & 136 & 32.3 & 169 & 40.1 & 421 & 100 \\
\hline
\end{tabular}

Source: Field Returns (2007).

Table 9 presents the methods of resolving domestic conflicts in the sampled housing areas as the research findings revealed. Over two-thirds, $193(68.44 \%)$ of the respondents confirmed that conflicts among the 
residents were usually resolved internally by elders, including landlords, within the house plus elders from adjoining houses on some occasions. About a quarter, $70(24.82 \%)$ of the respondents stated that conflicts were resolved by elders and mediators from the larger community, such as members of the executive committee of landlords' association, community leaders ("Baale" or Ward Chief), and opinion leaders. While 17 (6.03\%) of the respondents stated that they had to report conflicts to the police for resolution, an insignificant $2(0.71 \%)$ claimed that the conflict they had was never resolved. This could be a domestic conflict that involved physical assault and perhaps injury considered by the victims as unpardonable and unforgettable.

Table 9. Methods of conflict resolution within the sampled houses

\begin{tabular}{lll}
\hline Methods & Frequency & Percent \\
\hline Resolved internally by Elders & 193 & 68.44 \\
Resolved by Elders/Mediators within the Community & 70 & 24.82 \\
Reported to the Police & 17 & 6.03 \\
No Resolution & 2 & 0.71 \\
Total & $\mathbf{2 8 2}$ & $\mathbf{1 0 0 . 0 0}$ \\
\hline
\end{tabular}

Source: Field Returns (2007).

\section{Indigenous Approach to Domestic Conflict Management}

The imperativeness of resolution of conflicts among occupants of dwellings of any descriptions cannot be overestimated. It is not only to mediate disputes, but also to create avenue for dialogue, promote love, peaceful co-existence, community participation, and sense of belonging. In Ondo city, the majority $(93.26 \%)$ of the sampled respondents agreed that resolution of domestic conflicts was largely handled internally in dwellings by elders or a third party who was adjudged neutral among the occupants living in the same dwellings or next to them. Mediators were invited from within the entire community when conflicts involved most of the occupants. While $6.03 \%$ of the respondents invited the police to resolve their disputes, the final and lasting resolution was still done by the elders in the community. This is one of the cultural values of the Nigerian society which is rooted in the indigenous knowledge systems of the people. Traditional, social and cultural institutions determine and guide the individual and group behaviours and are highly cherished. The conflicting individuals or groups are more disposed, most of the time, to accepting decisions or rulings or pronouncements from the elder-mediators (among whom they live) than from other sources, like the police or formal courts. In fact, there is an adage among the Yoruba of Nigeria that says: a kii ti kotu de sore (we don't return from court and remain friends). The court here incorporates the police, who are seen as agent of the court.

This indigenous participatory approach to domestic conflict management in the sampled communities in Ondo attests to what Pkalya et al. (2004) observe about the potency of local (traditional) mediation. In these communities, elders and community leaders are held in high esteem and accepted as men and women of wisdom, and impeccable characters whose pre-occupation is the peaceful co-existence among their kith and kin. When these elders mediate in a conflict, their ultimate aim is to reconcile the guilty with the not-guilty in a way that satisfies both parties. The verdict guilty that may be pronounced on the offending party would be done in a way that would not constitute irredeemable shame and any loss of face.

Indigenous conflict management approach hardly involves any monetary cost and consumes less time in adjudication unlike the Western approach through the police or the court, which demands hiring of a lawyer to plead the case and several days of court appearances and adjournments (as it is in Nigeria). The mediators use persuasive words, stories, and ancestral references to make the conflicting parties calm down and understand the need to have the conflict resolved with the pledge not to allow a reccurrence. Persuasive statements are used to emphasize that conflicts are common when people co-habit, such as: agbemaja kan kosi, aja ma tan ni kodara (no two or more people who co-habit that do not quarrel, but what is bad is non-resolution of the quarrel); bi ako baja a kido're (if we don't quarrel we won't become friends).

\section{Conclusion}

The inability of housing units to provide equal access to basic facilities and services amongst its occupants has resulted in domestic conflicts. Domestic conflicts were more prevalent in face-to-face type of buildings because of lack of personal privacy, higher occupancy rate, inadequate or complete absence of basic facilities, and lack of 
required maintenance by the house owners in most cases. Domestic conflicts were minimal in multiple flats and self-contained house types owing to improved privacy and provision of basic facilities which were exclusive to and well maintained by the occupants. Poverty is another cause of domestic conflicts. The study showed that conflicts can and do occur in all types of housing though in varying degrees. Domestic conflict in residential communities of Ondo affected the house occupants psychologically, generated noisy environment, affected hearing, created distractions, and resulted in unclean environment. However, whenever there were conflicts among residents, they were mostly resolved using the indigenous approach.

In conclusion, indigenous methods of conflict resolution are the most popular means of resolving domestic conflicts in the study area. This is particularly so because traditional norms are still held in high esteem. In the various wards in Ondo city, elders devoted time, energy and other personal resources to intervening to resolve any form of conflict within their communities. In the process, they act as enforcers of community norms, values, laws and customs and are able to reduce incidents of conflict. Whenever any conflict occurs among residents, the traditional mediation mechanisms put in place are efficient and effective to resolve such conflict at least cost in terms of time, finance and disruption of socio-economic activities of the residents in conflict. This means of resolving conflict always leads to a revaluation of who we are as human beings in relation to how we ought to relate in mutually beneficial ways with our co-occupants.

\subsection{Recommendations}

The indigenous "cost-free" resolution mechanisms have been applied to resolve domestic conflicts in housing areas in Ondo city. Therefore, indigenous approaches to conflict resolution should be re-evaluated and promoted to suit contemporary challenges arising from daily human interactions in residential areas. The following recommendations are put forward in this regard:

Landlord-tenants associations should be encouraged in all wards to promptly handle conflicts among housing residents, with the chairmen of each local government community development council empowered to manage the local mediation structures.

The traditional institutions, such as the Osemawe of Ondo-in-Council, the ward chiefs and the compound chiefs, should be empowered by government to continually play mediator roles in domestic conflicts and civil matters in their areas and reduce court cases to the barest minimum.

Conflict resolution institution-building should be given serious consideration by the local government through its community/social development unit. Capacity-building workshops on traditional conflict management techniques should be organised at ward and community level for non-governmental organisations, community-based organisations, faith-based organisations, youth leaders, and women groups.

Ondo State and Ondo West Local Government should make available soft loans with low interest rates to landlords and house-owners to provide or rehabilitate their housing facilities in order to improve the standard of living in the communities and reduce domestic conflict among residents. The government should also provide public sanitation facilities in the form of comfort stations and water facilities in residential areas of each ward and charge user fees to sustain the maintenance of the facilities.

Both the state and local governments as well as private property developers should also embark on mass housing provision in newly developing areas of the city to decongest the existing crowded and facility-deficient residential communities. Indigenous environmental sanitation knowledge and practices should be evoked within the communities whereby residents communally collaborate to provide and manage housing facilities, especially water, toilets, and waste dumps (Wahab, 2004). Environmental health officers should work with traditional institutions to enforce hygiene and sanitation laws to promote healthy living among residents and reduce conflict. The Area Town Planning Office in the city should also work with landlord-tenant associations to ensure that new houses comply with building regulations on minimum number of basic facilities per dwelling.

\section{References}

Afrol News. (2007). Half of Nigeria's women experience domestic violence. Retrieved May 22, 2008, from http://www.afrol.com/articles/16471

Agbola, T., \& Kassim, F. (2007).Conceptual and theoretical issues in housing. In T. Agbola, L. Egunjobi, \& C. O. Olatubara (Eds.), Housing development and management: A book of readings (pp. 15-69). Ibadan: Department of Urban and Regional Planning, Faculty of the Social Sciences, University of Ibadan.

Aihie, O. N. (2009, May). Prevalence of domestic violence in Nigeria: Implications for counselling. Edo Journal of Counselling, 2(1). Retrieved from http://www.ajol.info/index.php/ejc/article/view/52648 
Akorede, V. E. A. (1995). Housing quality and the pattern of urban population density in Ondo town of Western Nigeria. Paper presented at the sixth Annual Conference of the Environmental and Behaviour Association of Nigeria (EBAN), Conference Centre, Obafemi Awolowo University, Ile-Ife, Nigeria. 28th - 30th March.

Albert, I.O. (2001). Introduction to third party intervention in community conflicts. Ibadan: John Archers Publishers Limited.

Albert, I. O. (2003). Mainstreaming: Positive leadership in conflict transformation in Nigeria. Lagos: Centre for Social Science Research and Development (CSSR\&D). Monograph Series. No 7. April 21, 2007: Forest Conflict in Asia United States Agency for International Development. Retrieved from http://www.forestconflict

Albert, I. O., Awe, T., Herault, G., \&Omiloogun, W. (Eds.). (1995). Informal channels of conflict resolution in Ibadan, Nigeria. Ibadan: IFRA.

Amaefule, E. (2011, July). 54 Percent Nigerian households have pit latrines, 66 per cent live in single rooms. Sunday Punch.

Amman, M. H., \& Duraiappah, A. K. (2011). Land tenure and conflict resolution: A game theoretic approach in the Narok district in Kenya. London: IIED and Amsterdam: Institute for Environmental Studies. CREED Working paper Series No. 37.

Atteh, D. O. (1992).Indigenous local knowledge as a key to local level development: Possibilities, constraints and planning issues in the context of Africa. Ames: CIKARD, Iowa State University Studies in Technology and Social Change, No. $20 . \quad$ Retrieved from http://www.amazon.com/Indigenous-local-knowledge-level-development/dp/0945271298

Baker, C. K., Cook, S. L., \& Norris, F. H. (2003). Domestic violence and housing problems a contextual analysis of women's help-seeking, received informal support, and formal system response. Violence against Women, 9(7), 754-783. http://dx.doi.org/10.1177/1077801203009007002

Baxi, U., \& Gallanter, M. (1979). Panchayat Justice: An Indian experience in legal access. In M. Cappelletti, \& B. Garth (Eds.), Access to Justice (pp. 314-386). Milano: Giuffered. Retrieved from https://www.ncjrs.gov/App/publications/abstract.aspx?ID=61175

Boswell, T., \& Dixon, W. J. (1993). Marx's theory of rebellion: A cross-national analysis of class exploitation, economic development, and violent revolt. American Sociological Review, 681-702. http://dx.doi.org/10.2307/2096281

Brock-Utne, B. (2001). Indigenous conflict resolution in Africa. A draft presented to the week-end seminar on indigenous solutions to conflicts held at the University of Oslo, Institute for Educational Research $23-24$ of February. Retrieved from http://www.africavenir.org/uploads/media/BrockUtneTradConflictResolution_02.pdf

Carter, L., \& Connor, K. (1989).A preliminary investigation of contemporary Afghan councils. Peshawar: ACBAR.

Castro, A. P., \& Ettenger, K. (1996).Indigenous knowledge and conflict management: exploring local perspectives and mechanisms for dealing with community forestry disputes. Paper Prepared for the United Nations Food and Agriculture Organization, Community Forestry Unit, for the Global Electronic Conference on "Addressing Natural Resource Conflicts through Community Forestry," January-April.

Chimaraoke, O. I. (2002). Participatory communal conflict resolution (PCCR) - a tale of two Nigerian local communities. PLA Notes, 43, 61-63. Retrieved from https://www.google.com/url?sa=t\&rct=j\&q=\&esrc=s\&source=web\&cd=2\&cad=rja\&ved=0CC8QFjAB\&url $=\mathrm{http} \% 3 \mathrm{~A} \% 2 \mathrm{~F} \% 2 \mathrm{Fpubs.iied.org \% 2Fpdfs \% 2FG01991.pdf \& ei=1tJ1Us6PLtDasgbQvIDADA \& usg=AFQjC}$ NEQZlbH928BnE_yYJ3mOTT-yW51BA\&bvm=bv.55819444,d.Yms

Clark, J. (1989). Conflict management outside the courtroom in China. In R. Troyer (Ed.), Social Control in the People's Republic of China (pp. 57-59). London: Prager Press.

Crowfoot, J. E., \& Wondolleck, J. M. (1990).Environmental Disputes: Community Involvement in Conflict Resolution. Washington, DC: Island Press.

Davis, R. (2010). Domestic Violence-related deaths. Journal of Aggression, Conflict and Peace Research, 2(2), 44-52. http://dx.doi.org/10.5042/jacpr.2010.0141

DuRant, R. H., Cadenhead, C., Pendergrast, R. A., Slavens, G., \& Linder, C. W. (1994). Factors associated with 
the use of violence among urban black adolescents. American Journal of Public Health, 84(4), 612-617. http://dx.doi.org/10.2105/AJPH.84.4.612

Dzurgba, A. (2010). Prevention and resolution of conflict: Local and international perspectives. Ibadan: John Archers Ltd.

Egunjobi, L. (1998). The links between housing and health. In B. Amole (Ed.), Habitat Studies in Nigeria (pp. 92-102). Ibadan: Shaneson C. I. Ltd.

Egunjobi, L., \& Osunwole, S. A. (1996).Integration of indigenous health systems into the education curriculum. In D. M. Warren, L. Egunjobi, \& B. Wahab (Eds.), Indigenous knowledge in education (pp. 55-62). Ibadan: Ageless Friendship Press.

Ellingsen, T. (2000).Colorful community or ethnic witches' brew? Multiethnicity and domestic conflict during and after the Cold War. Journal of Conflict Resolution, 44(2), 228-249. Retrieved from http://www.jstor.org/stable/174664

Enyioma, O. S. (2011). Basics of conflict resolution. Owerri: Centre for Peace and Conflict Transformation.

Faleti, S. A. (2006). Theories of social conflict. In G. Shedrach (Ed.), Introduction to Peace and Conflict Studies in West Africa: A Reader. Ibadan: Spectrum Books.

Gang, R. (2011).Community-based conflict resolution processes in Kabul city. Retrieved from http://www.areu.org.af

Guleid, A. A. (2007). History of conflict among the pastoralists in Eastern Africa and the role of traditional conflict resolution mechanisms. In W. G. C.Smidt, \& K.Abraham (Eds.), Discussing conflict in Ethiopia: Conflict management and resolution (pp. 14-22). Zurich: LIT Verlag GmbH \& Co.KGWien.

Howes, M., \& Chambers, R. (1979). Indigenous technical knowledge: analysis, implications and issues in rural development; whose knowledge counts? IDS Bulletin, 10(2), 6-11.

Humphries, J. (2002). Local government using participatory methods to facilitate stakeholder dialogue and conflict resolution. PLA Notes, 44, 19.

Hwang, K. K. (1998). Guanxi and mientze: Conflict resolution in Chinese society. Intercultural Communication Studies, 7, 17-42.

Johnston, J. R. (1994). High-conflict divorce: The future of children. Children and Divorce, 4(1).Retrieved from http://www.princeton.edu/futureofchildren/publications/docs/04_01_09.pdf

Kehinde, F. O. (2010). Managing the conflict between landlords and tenants in Lagos State. Unpublished Master Dissertation, Institute of African Studies, University of Ibadan.

Lauby, M., McCarty, K., Meade, J., \& White, L. S. (2006). 2003 Massachusetts domestic violence homicide report. Boston: Jane Doe Inc. Retrieved May, 2014, from http://www.janedoe.org/know/2003\%20MA\%20DV\%20Homicide\%20Report.pdf

Lefevre, E., Colot, O., \& Vannoorenberghe, P. (2002).Belief function combination and conflict management. Information Fusion, 3(2), 149-162. http://dx.doi.org/10.1016/S1566-2535(02)00053-2

Lewins, R. (2001). Consensus building and natural resource management: a review. CEMARE Research Paper, 157. Portsmouth: University of Portsmouth. Retrieved from http://www.port.ac.uk/research/cemare/publications/pdffiles/researchpaperspdf/filetodownload,71359,en.pd $\mathrm{f}$

Libiszewski, S. (1991). What is an environmental conflict? Journal of Peace Research, 28(4), 407-422. Retrieved from http://www.css.ethz.ch/publications/pdfs/What_is_Environment_Conflict_1992.pdf

Liu, J., \& Palermo, G. B. (2009).Restorative justice and Chinese traditional legal culture in the context of contemporary Chinese criminal justice reform. Asia Pacific Journal of Police \& Criminal Justice, 7(1), 49-68. Retrieved fromhttp://www.aaps.or.kr

Meschievitz, C. S., \& Galanter, M. (1982). In search of Tiyaytt Ranchayats: The politics of a moribund institution. The Politics of Informal Justice, 2. $\quad$ Retrieved from http://marcgalanter.net/Documents/papers/scannedpdf/insearchofnyayapanchayats.pdf

Moore, E. (1985). Conflict and compromise: Justice in an Indian village. New York: New York University Press. Morales-Gomez, D. A. (1993, April). Knowledge, change and the preservation of progress. IDRC Reports, pp. 
4-5.

Obaro, O. A. (2013). Theoretical nexus between social values, deviance and security in Nigeria. Academic Journal of Interdisciplinary Studies, 2(3), 391-396.

Odetokun, O. S. (2007). Domestic conflict and housing facilities in Ondo town. Unpublished M.Sc. Dissertation, Department of Urban and Regional Planning, University of Ibadan, Ibadan.

Olatubara, C. O. (2007). Fundamentals of housing. In T. Agbola, L. Egunjobi, \& C. O. Olatubara (Eds.), Housing development and management: A Book of Readings (pp. 70-106). Ibadan: Department of Urban and Regional Planning, Faculty of the Social Sciences, University of Ibadan.

Olesen, A. (1995). Islam and politics in Afghanistan. Curzon: Surrey, UK: Curzon Press.

Olokesusi, F. (1997).Managing environmental conflicts in Nigeria's petroleum industry: The role and strategies of mediation. Ibadan: JOSCOMF Nigeria Ltd.

Olutayo, A. O. (2007). Sociology of Housing. In T. Agbola, L. Egunjobi, \& C. O. Olatubara (Eds.), Housing development and management: A book of readings (pp. 150-172). Ibadan: Department of Urban and Regional Planning, Faculty of the Social Sciences, University of Ibadan

Ondo State Government. (2012). About Ondo. Retrieved from http://ipinleondo.com/myondostate/aboutondo.php

Otite, O., \& Albert, I. O. (Eds.). (1999). Community conflicts in Nigeria: Resolution, management and transformation. Ibadan: Spectrum Books Limited.

Oyediran, K. A., \& Isiugo-Abanihe, U. C. (2005).Perceptions of Nigerian Women on Domestic Violence: Evidence from 2003 Nigeria Demographic and Health Survey. African Journal of Reproductive Health, 9(2), 38-53. Retrieved from http://www.bioline.org.br/request?rh05024

Oyeshola, O. P. (2005). Conflict and context of conflict resolution. Ile-Ife: ObafemiAwolowo University Press.

Öztürk, S. (2004).Socio-Economic Role of Underclass. MuğlaÜniversitesi, SBE DergisiBaharSay1 12. Retrieved from http://www.sbed.mu.edu.tr/index.php/asd/article/viewFile/137/141

People's Republic of China State Council. (1989). Rules for organization of people's mediation committees. Beijing: Law Press.

Pkalya, R., Adan, M., Masinde, I., Rabar, B., \&Karimi, M. (2004). Indigenous democracy: Traditional conflict resolution mechanisms: Pokot, Turkana, Samburu and Marakwet. Nairobi: Intermediate Technology Development Group- Eastern Africa. pp. 118

Poelmans, J., Elzinga, P., Viaene, S., \&Dedene, G. (2010). Curbing domestic violence: instantiating C-K theory with formal concept analysis and emergent self-organizing maps.Intelligent Systems in Accounting, Finance and Management, 17(3 - 4), 167-191.

Radcliff, E. B., Ouedraogo, A., Patten, S. E., Ragsdale, D. W., \& Strzok, P. P. (1995). Neem in Niger: A new context for a system of indigenous knowledge. In D. M. Warren, L. J. Slikkerveer, \& D. Bronkehsha (Eds.), Cultural dimension of development (pp.35-70). London: Intermediate Publications.

Reichel, P. (1998). Comparative criminal justice system. New York: Prentice-Hall.

Richards, P. (1989). Indigenous agricultural knowledge and international agricultural research. In P. Richards, L. J. Slikkerveer, \& A. O. Phillips (Eds.), Indigenous Knowledge Systems for Agriculture and Rural Developments: The CIKARD Inaugural Lectures (pp. 4-18). Ames: CIKARD, Iowa State University. Studies in Technology and Social Change, No. 13.

Robinson, M. L. (2009). Just conflict: Harnessing the transformative power of conflict to create just relationships. Retrieved from http://www.creativeconflictresolution.org/JustConflicta.pdf

Rodriguez, I. (1998). Using PRA for conflict resolution in national parks: Lessons from a Venezualan experience in Canaima National Park.PLA Notes 33, 3-10. London: IIED.

Roseberg, M. L., O'Carroll, P. W., \& Powell, K. E. (1992). Let's be clear: violence is a public health problem. JAMA, 267(22), 3071-3072. http://dx.doi.org/10.1001/jama.1992.03480220089034

Scholte, P. S., Adam, S., Kari, S., \& Mbouche, J. (1999). Walking a Tight rope: Using PRA in Conflict situation around Waza National Park, Cameroon. PLA Notes 35: 7-12. London: IIED.

Simmie, J. (1980).Citizen in conflict: The sociology of town planning. London: Hutchinson \& Co. Publishers Ltd. 
Swift, J. (1979). Notes on traditional knowledge, modern knowledge, and rural development. IDS Bulletin, 10(2), 41-43. http://dx.doi.org/10.1111/j.1759-5436.1979.mp10002007.x

Titilola, T., Egunjobi, L., Amusan, A., \& Wahab, B. (1994). Introduction of indigenous knowledge into the education curriculum of primary, secondary and tertiary institutions in Nigeria: A policy guide. Ames: CIKARD, Iowa State University.

Toolbox. (2012). Tool Category B: Non-official conflict management methods 4. Indigenous conflict management mechanisms (Community-Based/Traditional/Indigenous Mediation; Community-Based Conflict Mitigation; Grassroots Approaches to Peace). Retrieved from http://www.creativeassociatesinternational.com/CAIIStaff/Dashboar

Umbreit, M. S. (1988). Mediation of victim offender conflict. J. Disp. Resol. 5, 85-105. Retrieved from http://scholarship.law.missouri.edu/jdr/vol1988/iss/5

Wahab, B. (2004). African traditional religions and environmental health and sanitation in rural communities. The Environscope, 1(1), 1-9.

Wahab, B. (2007). Elements of rural housing. In T. Agbola, L. Egunjobi, \& C. O. Olatubara (Eds.), Housing development and management: A book of readings (pp. 419-498). Ibadan: Department of Urban and Regional Planning, Faculty of the Social Sciences, University of Ibadan.

Wahab, B. (2010). Indigenous knowledge and development process. Lead paper presented at the First Ibadan Sustainable Development Summit organized by the Centre for Sustainable Development, University of Ibadan held at the Conference Centre, University of Ibadan, November 5.

Wahab, W. B. (1996). Indigenous knowledge systems and the human settlements: Towards integration into education curriculum. In D. M. Warren, L. Egunjobi, \& B. Wahab (Eds.), Indigenous knowledge in education (pp. 63-77). Ibadan: Indigenous Knowledge Study Group, University of Ibadan.

Wardak, A. (2005). Jirga - A traditional mechanism of conflict resolution in Afghanistan. Retrieved from http://unpan1.un.org/intradoc/groups/public/documents/APCITY/UNPAN017434.pdf

Warren, D. M. (1996). Indigenous knowledge systems for sustainable agriculture in Africa. In V. U. James (Ed.), Sustainable development in third world countries (pp. 15-24). Westport: Praeger.

Warren, D. M., \& Rajasekaran, B. (1993). Putting local knowledge to good use. International Agricultural Development, 13(4), 8-10.

Warren, D. M., Slikkerveer, L. J., \&Brokensha, D. (Eds.). (1995). The cultural dimension of development-Indigenous Knowledge Systems. London: Intermediate Technology Publications.

Websdale, N. (2003). Reviewing domestic violence deaths. NIJ Journal, 250, 26-31. Retrieved from https://www.ncjrs.gov/pdffiles1/jr000250g.pdf

WHO. (1976). Traditional medicine and its role in the development of Africa. WHO Document No. FR/RC26/TD/I. Geneva: WHO.

Widom, C. S. (1989). Does violence beget violence? A critical review of the literature. Psychol Bull, 106(1), 3-28. http://dx.doi.org/10.1037/0033-2909.106.1.3

Witgen, B., \& Wahab, B. (1997). The Influence of Alaafia on the design and development of Yoruba housing: A case study of Ibadan and Iseyin. In D. M. Warren, L. Egunjobi, \& B. Wahab (Eds.), Studies of the Yoruba Therapeutic System in Nigeria (pp. 98-116). Ames: Technology and Social Change Program, Iowa State University Research Foundation.

\section{Copyrights}

Copyright for this article is retained by the author(s), with first publication rights granted to the journal.

This is an open-access article distributed under the terms and conditions of the Creative Commons Attribution license (http://creativecommons.org/licenses/by/3.0/). 